\title{
Wave exposure indices from digital coastlines and the prediction of rocky shore community structure
}

\author{
Michael T. Burrows*, Robin Harvey, Linda Robb
}

Department of Ecology, Scottish Association for Marine Science, Dunstaffnage Marine Laboratory, Oban, Argyll PA37 1QA, UK

ABSTRACT: Topographical wave exposure indices allow objective assessment of the degree of wave action at coastal sites. We present a grid-based method for rapidly calculating indices at fine spatial resolutions along whole coastlines, and evaluate the power of candidate indices in predicting composition of rocky shore communities. The method has 3 stages: (1) a grid is created from a vector-based digital coastline using geographical information systems (GIS) software; (2) for every coastal cell, wave fetch is determined as the distance to the nearest land cell in 16 angular sectors, using coarse-, medium- and fine-resolution searches of the surrounding cells up to a distance of $200 \mathrm{~km}$; (3) wind energy (average wind speed and proportional occurrence) in each sector is calculated for nearby coastal sites. We calculated the average fetch in each sector $(F)$ and the sum of products of fetch and wind energy $(W)$. A total of 57 species were surveyed at 185 sites in west Scotland for determination of trends with wave indices. Average wave fetch with a $200 \mathrm{~m}$ scale grid explained $>50 \%$ of the variation in the first principal component of the species-sites abundance matrix, with shore extent explaining another $10 \%$. Incorporating wind data in the indices had a negligible effect on predictive power. Species diversity explained $61 \%$ of the variance in the second principal component and declined from low to high pelagic primary productivity. Separating direct physical effects from biological effects, such as food supply or grazing could potentially help us better understand the processes structuring biological communities on rocky shores.

KEY WORDS: Wave fetch - Wave exposure - Rocky shores · Digital coastlines · Community structure

Resale or republication not permitted without written consent of the publisher

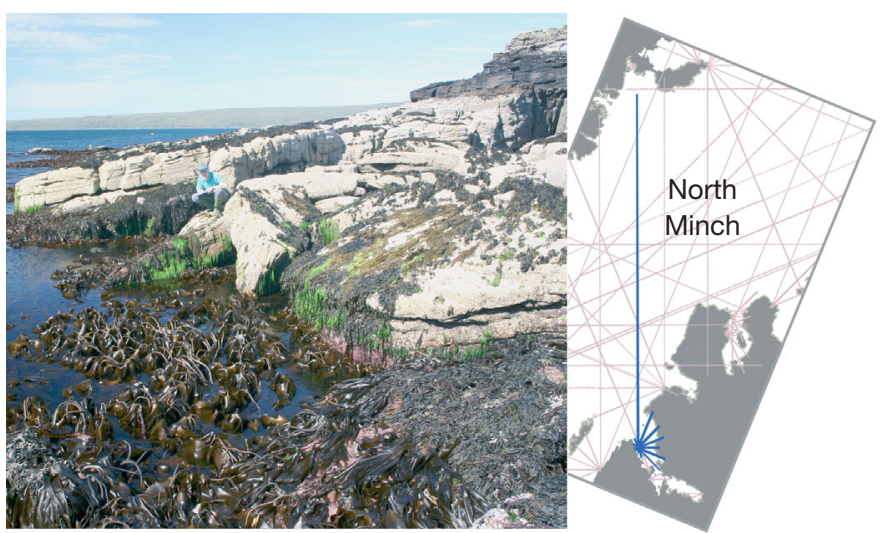

The composition of rocky shore communities (left) along whole coastlines can be predicted directly from GIS-based wave fetch indices (right; northwest Scotland).

Photo: M. T. Burrows

\section{INTRODUCTION}

It has long been known that biological communities on rocky shores are strongly influenced by wave exposure (Lewis 1964, Stephenson \& Stephenson 1972). However, despite the continuing need for a quantitative measure or index of the wave climate over a range of spatial and temporal scales, no single approach currently prevails. Biological indices of wave exposure based on the abundance of key taxa (Ballantine 1961) have proved useful for rapid categorisation of likely wave conditions, but suffer from an inherent circularity of reasoning and cannot be used to predict the composition of communities at sites not yet surveyed. Topographical indices, usually based on the openness and aspect of a site combined with local wind data, have been shown to have useful predictive power (Thomas 1986). These indices are relatively easy to produce, as 
only coastal charts and readily available meteorological data are needed, but it is potentially timeconsuming to derive predictions for more than a few sites. Perhaps the best measures of wave climate are those made directly on the shore using wave force dynamometers, which either record continuously (e.g. Denny 1982) or produce a measure of maximum force integrated over a period of deployment (Jones \& Demetropoulos 1968, Palumbi 1984, Helmuth \& Denny 2003). These measures are better in that they directly quantify the forces experienced by animals and plants on the shore. They do, however, rely on the deployment and retrieval of instruments and thus more than one visit to each site. Small-scale spatial variability in the forces of waves (Denny et al. 2004) may mean that single instruments may be unrepresentative of the whole shore wave climate and considerable periods of measurement may be necessary to capture rare, yet important, extreme events.

Despite the availability of these methods, where studies use more than one site on rocky coastlines, these sites are most often simply assigned to categories (sheltered, moderately exposed, very exposed, e.g. Burrows et al. 1992) based on subjective interpretation of the local geography and appearance of shore communities: effectively an informal application of biological indices. While rankings or groupings of sites in this way are unlikely to be wrong by more than one category, and can reveal effects of wave exposure on key processes, the effects reported are not easily comparable with other work since the categories are usually not defined in quantifiable terms. Clear, reproducible and objective measures of wave exposure would allow precise and portable definitions. The categorisation process may well lead to different conclusions than when wave exposure is considered as a continuous variable (Lindegarth \& Gamfeldt 2005). In view of the relative merits of each type of wave exposure measure, topographical indices may be the most practical and cost-effective option for field ecologists.

Topographical wave exposure indices have been used to determine the effects of wave exposure on distributions of species, such as mussels Mytilus edulis (Westerbom \& Jattu 2006), along horizontal wave action gradients, and have proved particularly effective at predicting effects on vertical limits (Thomas 1986). Within certain species, the link between wave exposure and morphology has been so strong as to have been exploited in the past to give a biological index of wave exposure. Dogwhelks Nucella lapillus, for example, show a progressive change from squat shells with small spires at wave-exposed sites to shells with elongated spires and narrower apertures in shelter, and the ratio of aperture length to total length of the shell has been used as an index (Crothers \& Cowell 1979,
Crothers 1983). However, these changes were related only to changes in assemblages. Using topographical indices is preferable: Fucus vesiculosus morphology was related strongly to calculated indices of wave exposure in the Baltic (Ruuskanen et al. 1999), for example. At the community level, clear relationships of assemblage composition and species diversity with wave exposure indices have also been shown (Lindegarth \& Gamfeldt 2005).

Where wave exposure indices can be calculated at regular intervals along coastlines, they may have value in constructing statistical models suitable for predicting distributions of species and community types (Bekkby et al. 2002). If such models are linked to climate variables, as climate envelope models (Pearson et al. 2002, Pearson \& Dawson 2003, Araújo et al. 2005), it may be possible to predict site-specific changes in abundance of species under different climate change scenarios-essential for designing future monitoring schemes. Similarly, it will be possible to predict changes in the spatial extent of community types, such as kelp forests, and thus changes in their contribution to the functioning of coastal ecosystems.

Finally, measurement or derivation of indices of wave exposure on geographical scales allows a macroecological approach (Gaston \& Blackburn 1999) to understanding the processes structuring rocky shore communities. If empirical relationships can be established between species distributions or community indices and measures of wave exposure (using statistical techniques), then it may be possible to detect the effects of interactions by comparing those states to expectations from purely physical models. Low or high abundances of grazers or predators may be associated with increased or reduced levels of plant biomass or prey numbers relative to values expected from wave exposure, depending on whether these systems are structured from the top-down or from the bottom up (Richardson \& Schoeman 2004).

The ready availability of geographical information systems (GIS) in recent years has prompted a number of authors to develop automated vector-based systems for deriving topographical indices of wave exposure based on digitised coastlines (Ekebom et al. 2003, Lindegarth \& Gamfeldt 2005, Puotinen 2005, Davies \& Johnson 2006). All these methods involve projecting radiating lines from points of interest, often corresponding to the location of sampling sites, to determine the wave fetch as the distance to the nearest coastline in angular sectors. Indices then divide into simple measures of 'openness' of coastlines, such as the Baardseth Index (Ruuskanen et al. 1999), measures based on the distribution and magnitude of fetch, often relative to the general direction of the shore (shore normals) (Denny et al. 2004), and indices weighted by the aver- 
age frequency and speed of wind in each angular sector for nearby meteorological stations (e.g. Davies \& Johnson 2006). Some authors then estimate wave height parameters (Ekebom et al. 2003, Harborne et al. 2006), measures that can ultimately be used to predict wave forces experienced by animals and plants on the shore (Helmuth \& Denny 2003).

Raster methods for determining wave fetch (such as 'viewshed' analysis, Bekkby et al. 2002) can offer much faster calculation of wave fetch for large numbers of locations very quickly (100 000s in a few hours), allowing mapping-style applications. We present a method of calculating wave fetch based on a hierarchical nested method of search for the nearest land in angular sectors around a point of interest, with increasingly fine spatial resolution of search at smaller spatial scales. The aim of the study was to evaluate the power of wave fetch-based indices of wave exposure at predicting differences in rocky shore community structure among sites over a large region, and to explore the utility of this predictive power in understanding processes generating ecological structure and function in these systems. By evaluating wave exposure indices for different scales of coastline grid size, we were also able to determine the optimal spatial grain scale for predicting results of shore surveys.

\section{MATERIALS AND METHODS}

Calculation of wave exposure indices. The method of calculation of wave exposure indices presented here requires a digital coastline dataset for the region of interest. We used the Global Self-consistent, Hierarchical, High-resolution Shoreline (GSHHS) dataset (NOAA; available at: www.ngdc.noaa.gov/mgg/shorelines/gshhs.html), based on the freely available World Vector Shoreline (NOAA; available at: www.csc.noaa. gov/shoreline/world_vec.html), for an area centred on the west coast of Scotland, extending as far south as the northern part of the Irish Sea, and as far north as the northern part of Orkney (Fig. 1d). The method requires a grid-based map of land and sea covering the region and beyond, extending to a distance which corresponds to the maximum fetch considered. We set this value to $200 \mathrm{~km}$ as the greatest distance that a search for nearby land could be fitted within the regional domain of the model, without exceeding the grid boundary. Fortunately, this distance also approximately corresponds with the 'transition point' (TP) where the fetch is long enough to consider wave conditions fully developed (Harborne et al. 2006, their Appendix A: TP $g F / U^{2}<22000$, where $g$ is acceleration due to gravity, $F$ is fetch and $U$ is wind speed in SI units) for most of the average wind speeds for the coastal stations. The TP for a 20 knot $\left(10.8 \mathrm{~m} \mathrm{~s}^{-1}\right)$ wind, for example, corresponds to a fetch of $237 \mathrm{~km}$. A GIS software package (ArcGIS 9.1) was used to project the vector dataset, using the British National Grid projection, and convert the vector dataset to gridded, or raster, datasets using specified spatial grain sizes (from $100 \mathrm{~m}$ to $20 \mathrm{~km})$.

Wave exposure indices were calculated for all the coastal cells in the grid. Land cells were identified as coastal when any of their 8 immediately adjacent cells were sea, giving sets of 163 coastal cells for the $20 \mathrm{~km}$ grid up to 183346 coastal cells for the $100 \mathrm{~m}$ resolution grid. The basis of the method was the determination of wave fetch, defined as the distance to the closest land, in each of 16 or 32 equal angular sectors $\left(22.5^{\circ}\right.$ or $\left.11.25^{\circ}\right)$. Each resolution of grid was examined with varying levels of spatial detail. By reducing the spatial intensity of the search for land at increasing distances from the location of interest (the focal cell), we were able to vastly increase the speed of the calculation and evaluate wave exposure for $>10^{5}$ cells in less than $1 \mathrm{~d}$. This was done by a 3 -scale search of neighbouring cells (Fig. 1a-c). The search process began by setting the minimum distance to land in each of the sectors to the maximum wave fetch. For every cell in the search, the distance and angular direction, and thus angular sector, from the focal coastal cell were calculated. If the cell was a land cell and the distance to that cell was less than the minimum recorded for that particular sector to that point in the search, then the minimum distance for the sector was set to the new distance value.

At the largest scale, one in every 100 cells in the $x$ and $y$-direction was scanned in a square region of side twice the maximum fetch value, centred on the focal cell (Fig. 1a). Next, one in every 10 cells was scanned in a smaller square region extending to $10 \%$ of the maximum fetch either side of the focal cell (Fig. 1b). Finally, every cell was scanned up to 10 cells away from the focal cell in an intensive local search (Fig. 1c). For areas of coastlines on narrow headlands, some sectors may appear open to wave fetch by falling between a diagonally adjacent cell and a horizontally or vertically adjacent cell. This was corrected by making a diagonally adjacent cell the closest cell in the 3 angular sectors falling in that cell. If land was present in an adjacent cell, the fetch distance in those sectors covered by the land cell were set to zero.

Wave fetch was determined and stored for each angular sector for every cell. Two indices were calculated. The first simpler index (average wave fetch, $F$ ), was the average wave fetch in $\mathrm{km}$ over all 16 sectors. The second index (wave exposure, $W$ ), was the average of the products of wave fetch and wind energy for each sector. Wind energy was calculated as the proportion of time that the wind blew in the particular sector 

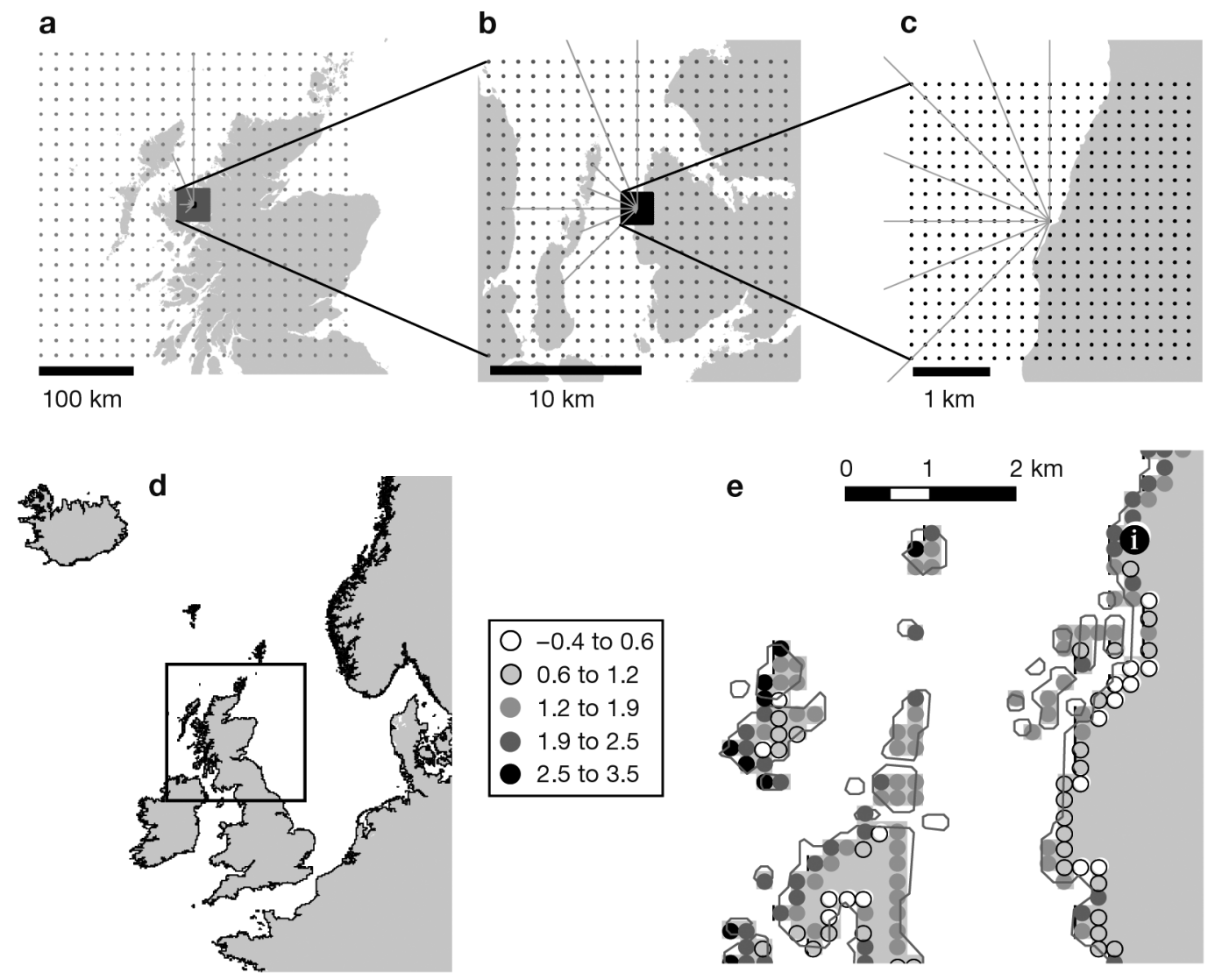

Fig. 1. $(\mathrm{a}-\mathrm{c})$ Three-scale search for the nearest land cells in coastal sectors around a single land cell at Lonbain, near Applecross, western Scotland. (a) $20 \mathrm{~km}$ interval search, (b) $1 \mathrm{~km}$ interval search, (c) $200 \mathrm{~m}$ interval search. Wave fetch values in $22.5^{\circ}$ sectors are shown as grey lines radiating from the focal cell. (d) Inset map shows the location of the study region in NW Europe. (e) An example local-scale map of wave fetch created using a $200 \mathrm{~m}$ grid. Symbols show $F$-values as $\log _{10} \mathrm{~km}$ for each coastal grid cell, and the letter $\mathrm{i}$ in the black circle shows the location of a sampling site

multiplied by the square of the average wind speed (in knots) in that sector. Hourly wind data for 1990 to 1999 for all weather stations (UK Meteorological Office; available at: badc.nerc.ac.uk/data/ukmo-midas) was used to calculate average wind speed and incidence per $22.5^{\circ}$ sector for coastal stations $(<5 \mathrm{~km}$ from the coast). Each cell was paired with the nearest weather station using GIS, and wind energy per sector calculated using this local data.

Conversion of the coastline from a line to a grid produces undesirable, but necessary, effects at very local scales. For example, straight coastlines running diagonally were rendered as step-like shapes (Fig. 1e). The consequence of this was that alternate cells along the coastline were blocked by their immediate neighbours, resulting in unrepresentative low values for wave fetch. Average values of wave fetch over all immediately adjacent cells create more representative values, at a potential cost of loss of spatial resolution of the index. Model code, a full description of the structure and operation of the model and wave fetch data produced for the UK are given in Appendices 1 \& 2, available as
Supplementary Material online at: (www.int-res.com/ articles/suppl/m353p001_app/).

Rocky shore surveys. The abundance of 58 species of rocky shore animals and plants was determined in surveys of 185 sites in the Western and Northern Isles and the mainland of Scotland in July and August 2002, 2003 and 2004. In each survey, each species was assigned to a single abundance category (Ex: extremely abundant; S: super abundant; A: abundant; C: common; F: frequent; O: occasional; R: rare; $\mathrm{N}$ : absent; Table 1) using scales created by Crisp \& Southward (1958) as modified by Hiscock (1981). Category estimates were based on counts in quadrats or visual assessment of the percentage cover in the area of the shore where the species was expected to be most abundant. Quadrats of $0.25 \mathrm{~m}^{2}$ were used for gastropod counts (trochids, littorinids and limpets) and to guide visual estimates of percentage cover, while areas of 4 to $100 \mathrm{~cm}^{2}$ were used for barnacle counts. The category occurring most often was used as the final category estimate for that species at that site. The advantage of these scales is that they can encompass levels of abundance not easily assessed by direct 
Table 1. Abundance scales used for intertidal organisms, after Crisp \& Southward (1958) modified by Hiscock (1981). Ex: extremely abundant; S: super abundant; A: abundant; C: common; F: frequent; O: occasional; R: rare. Organisms not seen during a $1 \mathrm{~h}$ site visit despite searching were recorded as N: absent

\begin{tabular}{|c|c|}
\hline Barnacles & F: Small patches, $5 \% ; \geq 10$ small ind. per $0.1 \mathrm{~m}^{2} ; \geq 1$ large \\
\hline Ex: $\geq 500$ per $0.01 \mathrm{~m}^{2}, \geq 5 \mathrm{~cm}^{-2}$ & ind. per $0.1 \mathrm{~m}^{2}$ \\
\hline S: $300-499$ per $0.01 \mathrm{~m}^{2}, 3-4 \mathrm{~cm}^{-2}$ & O: $1-9$ small ind. per $0.1 \mathrm{~m}^{2}: 1-9$ large ind. $\mathrm{m}^{-2}$; no patches \\
\hline A: $100-299$ per $0.01 \mathrm{~m}^{2}, 1-2 \mathrm{~cm}^{-2}$ & except small ind. in crevices \\
\hline C: $10-990.01 \mathrm{~m}^{-2}$ & $\mathrm{R}:<1 \mathrm{~m}^{-2}$ \\
\hline F: $1-9$ per $0.01 \mathrm{~m}^{2}$ & Pomatoceros sp. \\
\hline O: $1-99 \mathrm{~m}^{-2}$ & $A: \geq 50$ tubes per $0.01 \mathrm{~m}^{2}$ \\
\hline $\mathrm{R}:<1 \mathrm{~m}^{-2}$ & C: $1-49$ tubes per $0.01 \mathrm{~m}^{2}$ \\
\hline Patella spp. $\geq 10 \mathrm{~mm}$, & F: $1-9$ tubes per $0.1 \mathrm{~m}^{2}$ \\
\hline Littorina littorea (juveniles \& adults), & O: $1-9$ tubes $\mathrm{m}^{2}$ \\
\hline L. mariae/obtusata (adults) & $\mathrm{R}:<1$ tube $\mathrm{m}^{-2}$ \\
\hline Ex: $\geq 20$ per $0.1 \mathrm{~m}^{2}$ & Spirorbinidae \\
\hline $\begin{array}{l}\text { S: } 10-19 \text { per } 0.1 \mathrm{~m}^{2} \\
\text { A: } 5-9 \text { per } 0.1 \mathrm{~m}^{2}\end{array}$ & A: $\geq 5 \mathrm{~cm}-{ }^{2}$ on appropriate substrata $;>100$ per $0.01 \mathrm{~m}^{2}$ \\
\hline C: $1-4$ per $0.1 \mathrm{~m}^{2}$ & generally \\
\hline F: $5-9 \mathrm{~m}^{-2}$ & C: Patches of $\geq 5 \mathrm{~cm}^{-2} ; 1-100$ per $0.1 \mathrm{~m}^{2}$ generally \\
\hline O: $1-4 \mathrm{~m}^{-2}$ & F: Widely scattered small groups; $1-9$ per $0.1 \mathrm{~m}^{2}$ generally \\
\hline $\mathrm{R}:<1 \mathrm{~m}^{-2}$ & O: Widely scattered small groups; $<1$ per $0.1 \mathrm{~m}^{2}$ generally \\
\hline Littorina 'saxatilis', & $\mathrm{R}:<1 \mathrm{~m}^{-1}$ \\
\hline Patella $<10$ mm, L.mariae/obtusata juv. & Sponges, hydroids, bryozoa \\
\hline Ex: $\geq 50$ per $0.1 \mathrm{~m}^{2}$ & A: Present on $\geq 20 \%$ of suitable surfaces \\
\hline S: $20-49$ per $0.1 \mathrm{~m}^{2}$ & C: Present on $5-19 \%$ of suitable surfaces \\
\hline A: $10-19$ per $0.1 \mathrm{~m}^{2}$ & F: Scattered patches; $<5 \%$ cover \\
\hline C: $5-9$ per $0.1 \mathrm{~m}^{2}$ & O: Small patch or single sprig in $0.1 \mathrm{~m}^{2}$ \\
\hline $\mathrm{F}: 1-4$ per $0.1 \mathrm{~m}^{2}$ & $\mathrm{R}:<1$ patch over strip; 1 small patch or sprig per $0.1 \mathrm{~m}^{2}$ \\
\hline $\mathrm{O}: 1-9 \mathrm{~m}^{-2}$ & Lichens, lithothamnia \\
\hline $\mathrm{R}:<1 \mathrm{~m}^{-2}$ & Ex: More than $80 \%$ cover 6 S $50-79 \%$ cover \\
\hline Nucella lapillus (>3 mm), Gibbula spp. & A: $20-49 \%$ cover \\
\hline Ex: $\geq 10$ per $0.1 \mathrm{~m}^{2}$ & C: $1-19 \%$ cover \\
\hline S: $5-90.1 \mathrm{~m}^{-2}$ & F: Large scattered patches \\
\hline A: $1-40.1 \mathrm{~m}^{-2}$ & O: Widely scattered patches all small \\
\hline C: $5-9 \mathrm{~m}^{-2}$, sometimes more & R: Only 1 or 2 patches \\
\hline F: $1-4 \mathrm{~m}^{-2}$, locally sometimes more & Algae \\
\hline $\mathrm{O}:<1 \mathrm{~m}^{-2}$, locally sometimes more & Ex: $>90 \%$ cover \\
\hline R: Always $<1 \mathrm{~m}^{-2}$ & S: $60-89 \%$ cover \\
\hline Mytilus edulis & A: $30-59 \%$ cover \\
\hline Ex: $\geq 80 \%$ cover & C: $5-29 \%$ cover \\
\hline S: $50-79 \%$ cover & F: $<5 \%$ cover, zone still apparent \\
\hline A: $20-49 \%$ cover & O: Scattered plants, zone indistinct \\
\hline C: $5-19 \%$ cover & R: Only 1 or 2 plants \\
\hline
\end{tabular}

counts from quadrats. Many quadrat counts of zero abundance might be needed to get a measure of abundance of a rare plant or animal, occurring only in isolated patches or as solitary individuals; however, the presence of species can be very important to record, especially in a biogeographical context. The process took about an hour to record all the species on the checklist, and covered the entire intertidal area over 50 to $100 \mathrm{~m}$ of shoreline. If the species was not seen during the shore survey despite a search, it was recorded as absent. Each survey was done within $2 \mathrm{~h}$ of the time of low water predicted for that date and location. The position of each shore survey was recorded at mid-shore using a handheld GPS (Garmin GPS72).

To verify the method of categorical abundance assessment at a subset of shores, we took digital photo- graphs of four $0.25 \mathrm{~m}^{2}$ quadrats at 5 shore levels, and made counts of 5 species of gastropods at 2 levels (50 $\mathrm{cm}$ above and below mid tide level) from these images after removal and weighing of the macroalgal canopy. The wet weight of the 4 main species of large macroalgae was recorded. We compared these direct measurements of abundance with categorical estimates using 1-way ANOVAs of log-transformed abundance. This calibration (Fig. 2) showed that, above category R, direct counts of gastropods and weights per unit area of macroalgae were well predicted by categorical estimates of abundance $\left(\mathrm{R}^{2}=0.04\right.$ to $0.39, \mathrm{p}<$ 0.05 for 8 of 9 species examined).

To reduce the dimensionality of the data and to extract measures of community structure for comparison with the wave exposure indices, a principal 
component analysis (PCA) was performed on a species-sites matrix. Categorical abundance data were converted to numeric data by assigning integer values to each category, combining the top 3 categories $(E x, S$ and A) into a single class. Intervals between categories are similar when the upper and lower values defining the categories are expressed as logarithms, so the unit
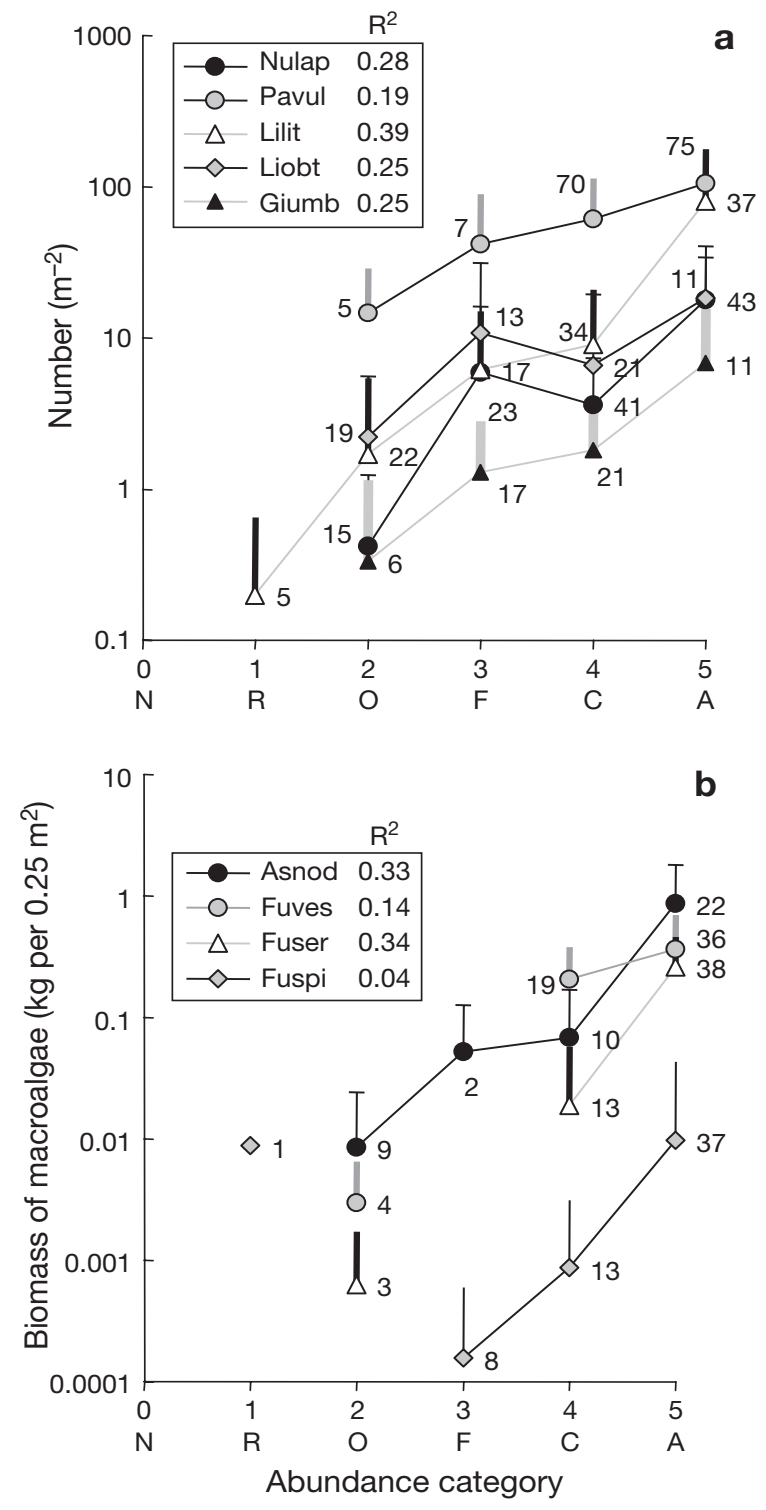

Fig. 2. (a) Average counts of 5 gastropod species from digital images of $0.25 \mathrm{~m}^{2}$ quadrats, and (b) average wet weights of macroalgae removed from $0.25 \mathrm{~m}^{2}$ quadrats, for different abundance categories. Symbols show mean values over the number of shores indicated. Error bars show + SD of the mean. Nulap: Nucella lapillus; Pavul: Patella vulgata; Lilit: Littorina littorea; Liobt: Littorina obtusata; Giumb: Gibbula umbilicalis; Asnod: Ascophyllum nodosum; Fuves: Fucus vesiculosus; Fuser: Fucus serratus; Fuspi: Fucus spiralis. $\mathrm{R}^{2}$ values give the proportion of variation in measured abundance explained by categorical abundance classes. Abundance category: N, absent; R, rare; $\mathrm{O}$, occasional; $\mathrm{F}$, frequent; $\mathrm{C}$, common; $\mathrm{A}$, abundant difference in the numerical values assigned to adjacent categories is approximately equivalent to a log transformation of the original data. Scores for each site were stored for the first 4 principal components extracted by the analysis.

Survey site locations were matched to the location of the centre of the nearest grid cell for which wave indices had been calculated. The horizontal extent of each surveyed shore was measured as the distance along a line perpendicular to the coastline from mean high water of spring tides (MHWS) to mean low water springs (MLWS) on 1:50000 UK Ordnance Survey Landranger maps.

Evaluation of predictive power of wave exposure indices. Preliminary analysis of the PCA scores and wave exposure indices showed that the first principal component score (PCA1) was very strongly correlated with wave exposure. The ability of different wave exposure indices to predict PCA1 scores was assessed by the proportion of variance in PCA1 explained in linear least-squares regression $\left(R^{2}\right) \cdot R^{2}$ values described the magnitude of effects of different spatial grain size $(100 \mathrm{~m}, 200 \mathrm{~m}, 500 \mathrm{~m}, 1 \mathrm{~km}, 2 \mathrm{~km}, 5 \mathrm{~km}, 10 \mathrm{~km}$ and $20 \mathrm{~km})$, the utility of including wind data in calculating exposure $(F$ vs. $W)$, and the effect of local spatial averaging of indices. The effect of the horizontal extent of shores was determined by regression of residual PCA1 scores, after regression on wave exposure indices, on extent values.

\section{RESULTS}

Wind roses for coastal stations around Scotland showed patterns of variation in wind flow in the region (Fig. 3) in the 1990s. Most coastal stations had the most frequent and strongest winds to the south and west, and least to the east and north (Fig. 3c). Winds were stronger on outer coasts (Fig. 3a) and weaker further from the open ocean (Fig. 3b). There was some modification in the average direction of wind flow by landmasses (Fig. 3c). East-facing coasts had less strong westerlies, resulting in an overall more southerly direction of wind. Some effects of local topography may also be evident: uneven distributions of wind directions were seen at several sites (e.g. Dunstaffnage, Fig. 3b). Sampling sites were located 0.4 to $91 \mathrm{~km}$, median $29.5 \mathrm{~km}$ from weather stations (Fig. 3d).

Geographical and local patterns of the average wave fetch index $(F)$ and average wave exposure $(W)$ followed general expectations. The outer coastlines of the Western and Northern Isles had the highest values of average wave fetch (40 to $60 \mathrm{~km}$ per sector), with open coasts of the Scottish mainland, partly sheltered by offshore islands, having lesser values (20 to $40 \mathrm{~km}$ ). 
a South Uist: (1)
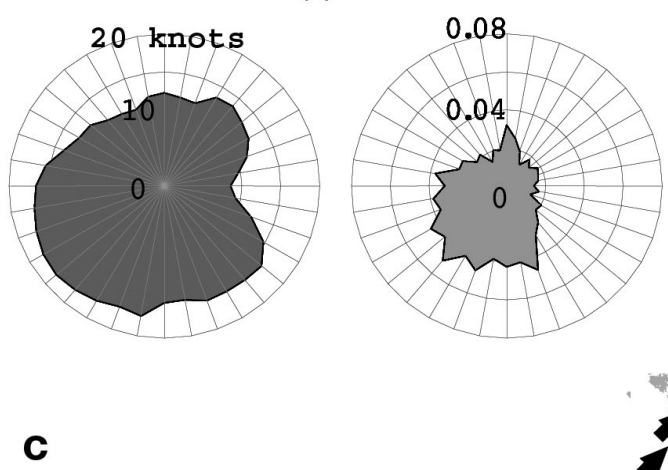

\section{b Dunstaffnage: (2)}

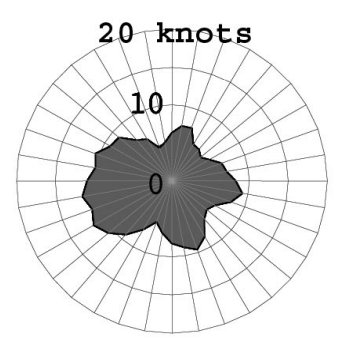

d

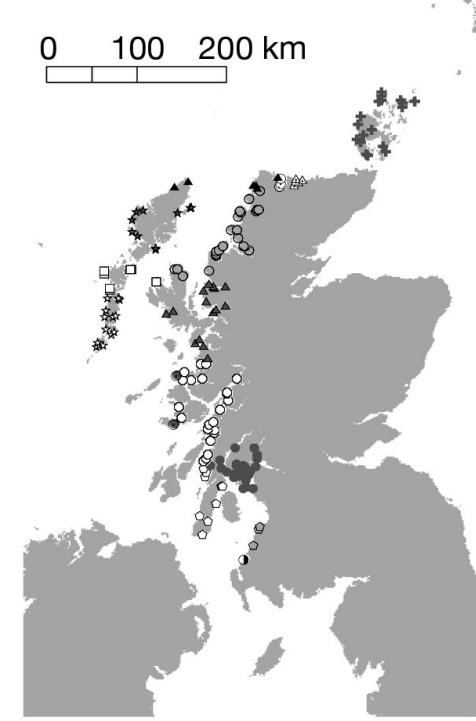

Fig. 3. Wind flow regime in northern UK 1990-1999. Wind data: shown for 2 example locations: (a) South Uist, labelled as (1) in (c), and (b) Dunstaffnage, labelled as (2). Wind roses show (left) mean wind speed, and (right) proportional incidence in $10^{\circ}$ sectors. The wind flow plot (c) shows average wind speed and average angle weighted by speed for each coastal site. Groups of survey sites sharing common weather stations are shown by unique symbols in (d)

Inlets and sea lochs (Fig. 1e) had much lower values (0.1 to $5 \mathrm{~km})$, reflecting their much more sheltered locations, often open to just the opposite shoreline of the loch. For comparison, a site on a straight open coast open to uninterrupted fetch out into the open ocean would have 8 out of 16 sectors with fetch values of the maximum $200 \mathrm{~km}$, giving an average wave fetch of $100 \mathrm{~km}$ per sector. Higher values would be possible for offshore headlands and islands.

The minimum fetch that could be resolved was directly related to the scale resolution of the coastal grid. This severely reduced the incidence of wavesheltered shores detected using coarser grids (Fig. 4).

\section{Ordination of rocky shore species data}

The PCA1 extracted from the species-sites matrix corresponded to the difference between wave-exposed and wave-sheltered communities. Species whose abundance values strongly positively correlated with PCA1 scores for each site were those considered typical of wave-exposed shores in the northeast Atlantic (Fig. 5). These included finely branching and turf species of macroalgae Corallina officinalis, Ceramium spp., Scytosiphon lomentaria, encrusting corallines in high shore pools ('lithothamnion'), Porphyra sp., the kelp Alaria esculenta, the barnacle Chthamalus stellatus, the dogwhelk Nucella lapillus and the anemone Actinia equina. Species strongly negatively correlated with PCA1 were typically sheltered-shore species, notably the brown fucoid algae Fucus vesiculosus (and the associated littorinid snail Littorina obtusata), F. spiralis, Ascophyllum nodosum (and its epiphyte Polysiphonia lanosa), Pelvetia canaliculata, and small encrusting tubeworms Spirorbis spp.

The PCA2 correlated positively with 48 out of the 58 species considered and negatively with only 8 species, notably Littorina littorea. This axis thus represents species diversity (PCA2 vs. number of species present, $\mathrm{R}^{2}=0.61, \mathrm{r}=0.78 ;$ Fig. $6 \mathrm{a}$ ). The scores for PCA2 showed a distinctive pattern among the different sites. Scores, and thus species diversity, were highest on offshore islands, and lowest in inner firths (Fig. 6b), but this dif- 


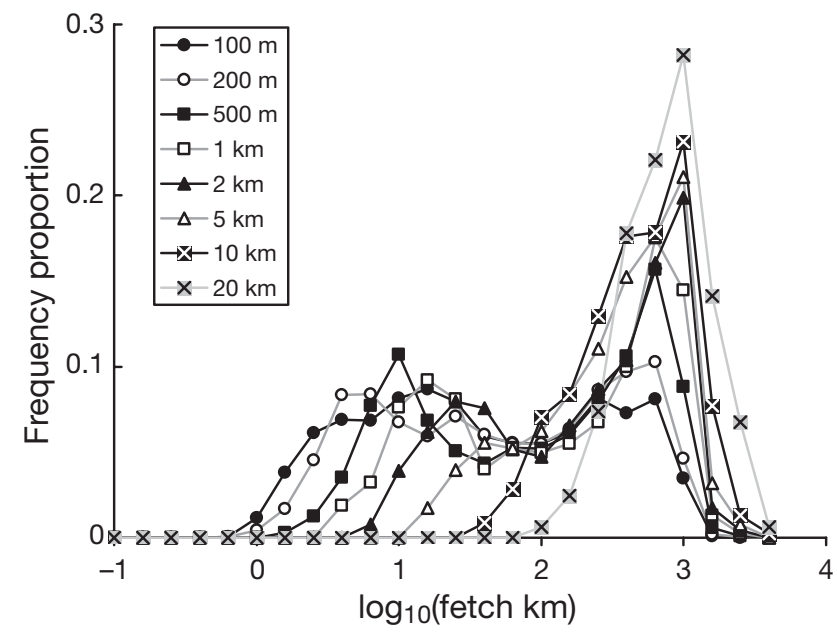

Fig. 4. Frequency polygons of fetch values calculated using spatial grids of $100 \mathrm{~m}$ to $20 \mathrm{~km}$ resolution showing the progressive loss of low fetch values with increasing cell size ference was not due to differences in wave fetch $\left(\mathrm{R}^{2}=\right.$ 0.02 for PCA2 vs. locally averaged $F$ for a $200 \mathrm{~m}$ grid).

\section{Comparison of predictive power of wave exposure indices}

$F$ was a very good predictor of the value of PCA1 score (Fig. 7), explaining over $50 \%$ of the variance in PCA1 (equivalent to a correlation coefficient of 0.7 ). The relationship between PCA1 and log average wave fetch was approximately linear over the whole range of wave exposures (Fig. 8), further indication of the value of the index in predicting differences in community structure.

The predictive ability of wave indices was strongly dependent on the scale of the grid representing the coastline (Fig. 7). The proportion of variance explained

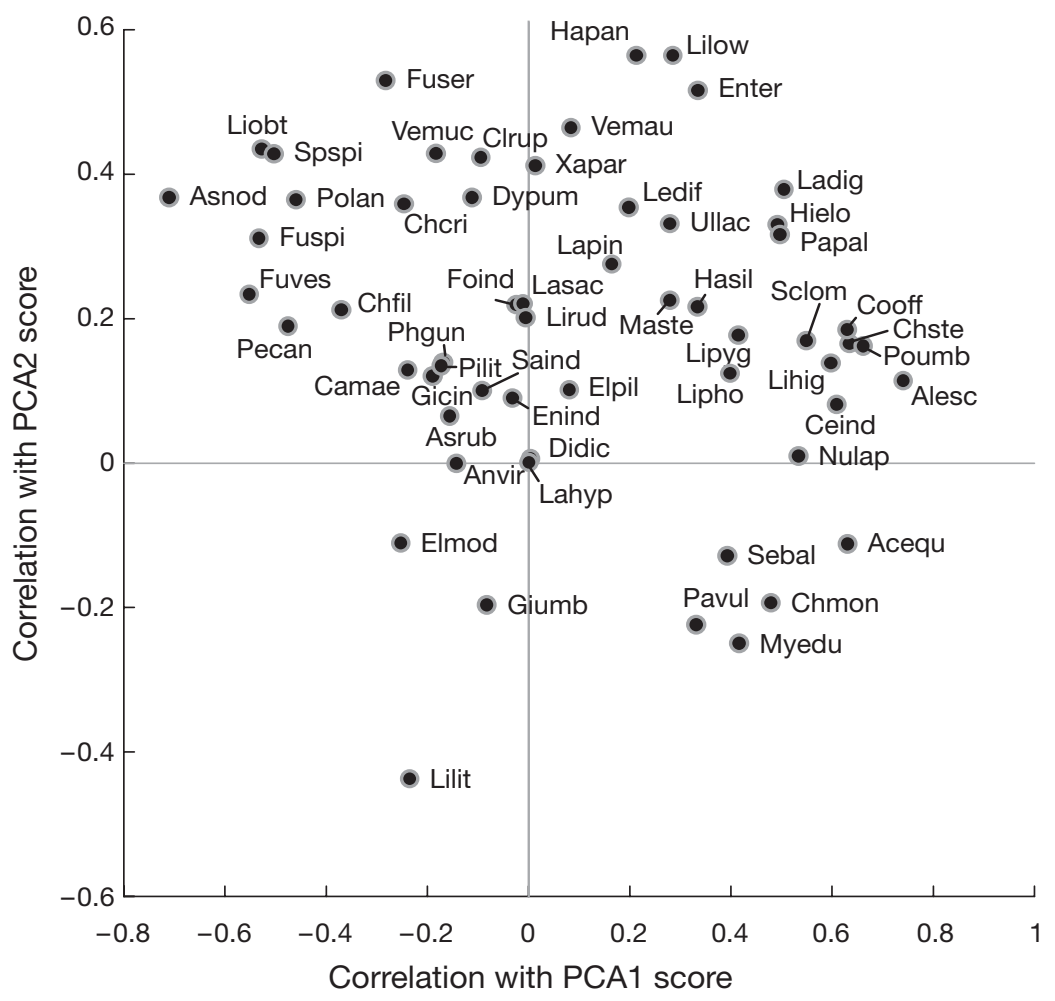

Fig. 5. Principal component analysis: ordination of species correlations with the first 2 principal components. Acequ: Actinia equina; Alesc: Alaria esculenta; Anvir: Anemonia viridis; Asnod: Ascophyllum nodosum; Asrub: Asterias rubens; Camae: Carcinus maenas; Ceind: Ceramium/Polysiphonia turf; Chcri: Chondrus crispus; Chfil: Chorda filum; Chmon: Chthamalus montagui; Chste: C. stellatus; Clrup: Cladophora rupestris; Cooff: Corallina officinalis; Didic: Dictyota dichotoma; Dypum: Dynamena pumila; Elmod: Elminius modestus; Elpil: Electra pilosa; Enind: encrusting algae (including Ralfsia spp.) species; Enter: Enteromorpha spp.; Foind: other foliaceous reds; Fuser: F. serratus; Fuspi: F. spiralis; Fuves: F. vesiculosus; Gicin: G. cineraria; Giumb: Gibbula umbilicalis; Hapan: Halichondria panicea; Hasil: Halidrys siliquosa; Hielo: Himanthalia elongata; Ladig: Laminaria digitata; Lahyp: L. hyperborea; Lapin: Laurencia spp.; Lasac: L. saccharina; Ledif: Leathesia difformis; Lihig: coralline crusts high pools; Lilit: L. littorea; Lilow: coralline crusts low rock; Liobt: L. obtusata; Lipho: Lipophrys pholis; Lipyg: Lichina pygmaea; Lirud: Littorina rudis; Maste: Mastocarpus stellatus; Myedu: Mytilus edulis; Nulap: Nucella lapillus; Papal: Palmaria palmata; Pavul: P. vulgata; Pecan: Pelvetia canaliculata; Phgun: Pholis gunnellus; Pilit: Pilayella littoralis; Polan: Polysiphonia lanosa; Poumb: Porphyra sp.; Saind: sand-binding algae; Sclom: Scytosiphon lomentaria; Sebal: Semibalanus balanoides; Spspi: Spirorbis spirorbis; Ullac: Ulva lactuca; Vemau: Verrucaria maura; Vemuc: V. mucosa; Xapar: Xanthoria parietina 


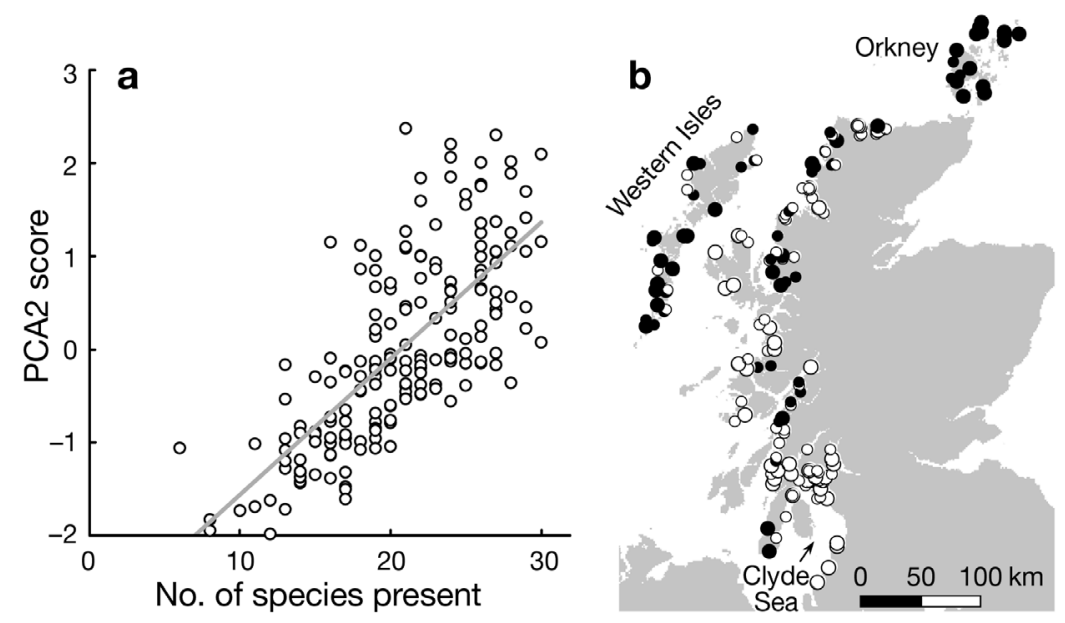

Fig. 6. (a) Second principal component (PCA2) scores related to the number of species recorded as present at survey sites, $\left(y=-2.99+0.13 x, R^{2}=0.61\right)$.

(b) Geographical distribution of PCA2 scores among sites showing positive (•) and negative values ( 0 ), with highest scores on offshore islands and lowest in inner firths

in PCA1 declined from a maximum of around 0.5 at a grid cell size of $200 \mathrm{~m}$ to less than 0.1 for cell sizes of 10 and $20 \mathrm{~km}$. Interestingly, the proportion of variance explained also dropped when cell size was reduced from 200 to $100 \mathrm{~m}$. Topographical effects on wave exposure at this local scale may not be reflected in differences in community structure. While the GSHHS shoreline may not be able to resolve coastline detail at this scale, the extent of the site surveys may also

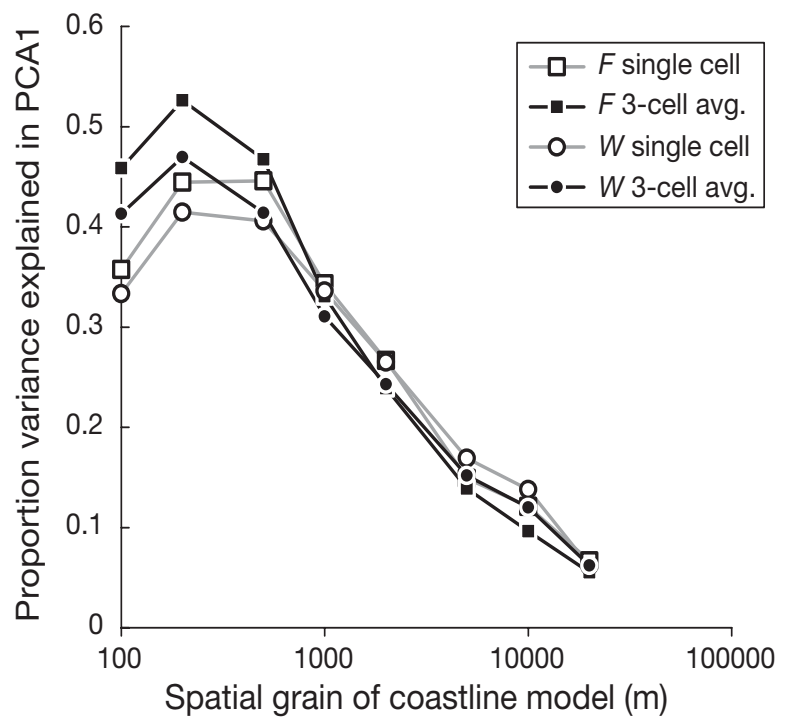

Fig. 7. Predictive power of wave fetch indices $(F$, average wave fetch; $W$, average wave exposure) for coastlines divided into different grid cell sizes, expressed as the proportion of variance in the first principal component (PCA1) explained by linear regression on index values. Data are presented for single cell values and for averages of 3-cell neighbourhoods around each cell extend over more than a single $100 \mathrm{~m}$ grid cell, and there may be a consequent poor match between survey data and exposure indices.

Inclusion of wind data reduced the predictive power of the indices (Fig. 7: F vs. $W$ ), especially at smaller scales. At the $200 \mathrm{~m}$ scale, without local averaging, $\mathrm{R}^{2}$ for $F$ was 0.444 and for $W 0.415$, a decrease of $3 \%$. After local averaging at this scale, $\mathrm{R}^{2}$ for $F$ was 0.526 compared with 0.470 for $W$, a $6 \%$ decrease.

Averaging values across neighbouring cells improved the predictive power of the indices at smaller scales (Fig. 7). With grid cell sizes of $1 \mathrm{~km}$ and larger, averaged values of $F$ and $W$ were slightly worse at predicting PCA1 $\left(1 \mathrm{~km} \mathrm{R}\right.$ R $^{2}$ averaged 0.330, F not averaged 0.343), while at the best grid size $(200 \mathrm{~m})$, averaging increased predictive power $\left(\mathrm{R}^{2} F\right.$ averaged 0.526, $F$ not averaged $0.444 ; W$ averaged $0.470, W$ not averaged 0.415).

Some of the residual variation in PCA1 was related to the horizontal extent of the shore (Fig. 9), the distance from MHWS to MLWS perpendicular to the coastline. PCA1 score was much reduced for extensive shores: a decrease of 1 relative to those $<50 \mathrm{~m}$ in extent for shores $400 \mathrm{~m}$ from MLWS to MHWS, an effect equivalent to an order of magnitude change in $F$ (Fig. 8).

\section{DISCUSSION}

Given the long-recognised effect of wave exposure on the composition of rocky shore communities (Ballantine 1961, Lewis 1964), the very strong predictive power of wave exposure indices in the present study was not at all surprising. What is surprising, however, in light of this predictive power, is the lack of general application of such indices as standardising or comparative measures in ecological studies on rocky shores. No physiological ecologist would neglect to report the temperature or salinity of their study, yet experimental shore ecologists are content to apply wide-ranging and ill-defined categorical descriptions for the wave exposure of their sites. Possible reasons for this failing may include: an unwillingness to obtain the charts and wind data needed to make calculations; a perception that such calculations are tedious and unnecessary given the seemingly obvious effects of wave action; and a disbelief in the value of such indices in capturing the essence of spatial variation in wave exposure and thus in predicting effects. The method presented here offers solutions to some of these perceived and real problems. 


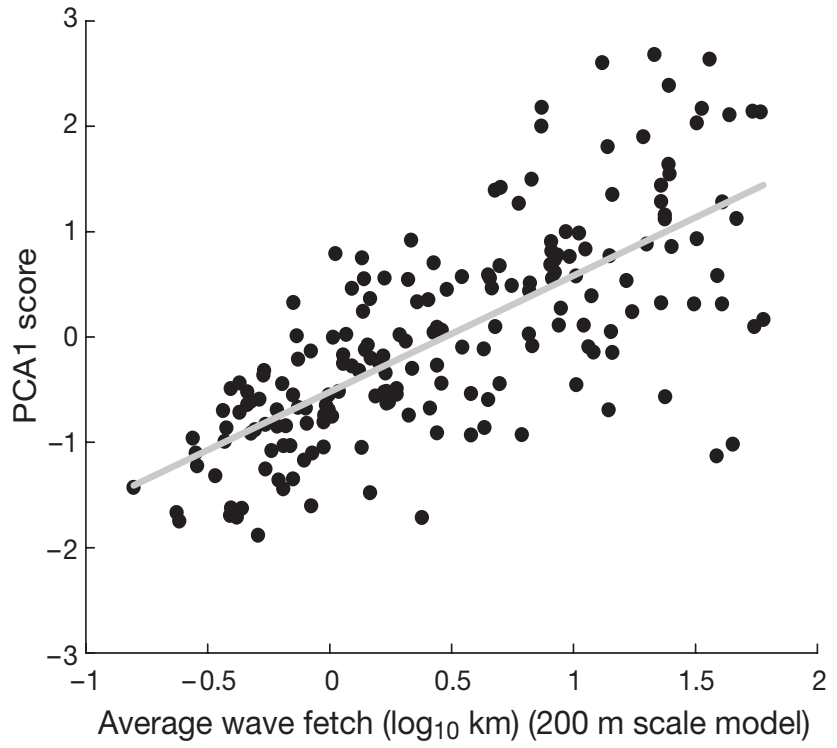

Fig. 8. Relationship between the first principal component (PCA1) of community structure and average wave fetch for 185 sites in western Scotland and offshore islands, calculated using a $200 \mathrm{~m}$ coastline grid. Linear regression line is shown $\left(y=1.105 x-0.522, \mathrm{R}^{2}=0.52, \mathrm{p}<0.001, \mathrm{n}=185\right)$

At best, the wave exposure indices explained over $50 \%$ of the variance in the PCA1 of community structure. Weighting indices with directional wind data had very little effect on the percentage variance explained, suggesting that, for complex coastlines like the west of Scotland, differences in topography alone rather than aspect were sufficient to account for differences in community structure. Sheltered sites tended to have 'sheltered-shore' communities and exposed shores 'exposed-shore' communities, whatever their orientation in respect to the prevailing wind. Based on this evi-

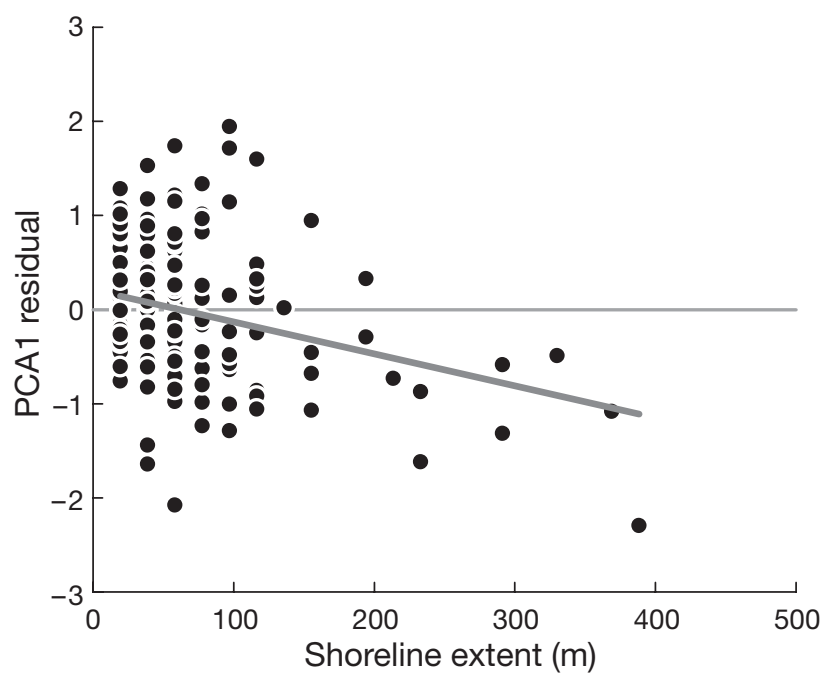

Fig. 9. Effect of shore extent on the residual of PCA1 from the value predicted from average wave fetch $(y=-0.0034 x+$ $0.21, \mathrm{R}^{2}=0.092, \mathrm{p}<0.001, \mathrm{n}=185$ ) dence, the effort involved in extracting and processing wind records from land-based meteorological stations would appear not to be repaid in additional predictive power for topographical wave exposure indices. The topography of the shore was important when the extent of the shore exceeded $100 \mathrm{~m}$, such that extensive reef flats produced a more 'sheltered-shore' community than predicted by wave fetch alone, especially at locations with extensive wave fetch such as on western coasts of the Western Isles. This explained an additional $10 \%$ of the variance in the PCA1 of community structure. Nearshore bathymetry can also play an important role in attenuating local wave power and inclusion of the extent of shallow water inshore in indices can improve their predictive ability (Thomas 1986) and could easily be incorporated in the present GIS-based raster calculation method. Fine-scale digital bathymetry, however, can be expensive to obtain and its absence would limit the applicability of this enhancement.

Variation in community structure in relation to wave fetch was not the only trend evident in the survey data. There was a strong gradient in species diversity independent of wave exposure, reflected in the second principal component of the community ordination (PCA2, Fig. 6a), from low diversity communities in the Clyde Sea and southern Scottish mainland sites to high diversity in Orkney and the Western Isles. Habitat complexity, either biogenic (Thompson et al. 1996) or physical (Beck 2000), may be responsible for variation in species diversity at a local scale. Habitat diversity (beta diversity), such as a complex of vertical and horizontal surfaces, pools, and crevices versus flat unbroken sloping strata, may be responsible for some of the differences among sites (Harborne et al. 2006). Interactions of the local species pool with the rock type of an area may also lead to differences in diversity (Johnson et al. 2003). Diversity may also simply reflect the availability of suitable rocky shore habitat at each of the survey sites. Boulder and cobble shores, for example, often lacked extensive exposed rock surfaces, yet frequently collected algal detritus in the interstices between the rocks. These gaps often supported very high densities of Littorina littorea, apparently feeding on this algal detritus.

In our region, increasing diversity coincides with a decreasing gradient of pelagic primary productivity evident from ocean colour satellites (European Commission, Ocean Colour Portal; available at: http://marine.jrc. cec.eu.int/). It is possible that higher pelagic productivity has produced communities that are dominated by filter feeders, which in turn reduces overall species diversity (Paine 1966). Indeed, of the 8 species correlated negatively with PCA2 (Fig. 5) 4 were filter feeders (Mytilus edulis, Semibalanus balanoides, Chthamalus montagui and Elminius modestus), 3 were micro- 
phagous grazers and 1 a predator: all were dependent on pelagic primary productivity. More diverse shores were generally more distant from the major towns and cities and areas of intensive agriculture in central Scotland, perhaps reflecting greater nutrient inputs in waste water and runoff from farmland. Extension of this trend to a wider geographical area would be a useful next step.

Offshore wave climate plays an important role in determining the height and thus energy of waves reaching the coastline. Data from offshore wave buoys, for example, have been used to calculate inshore wave height for comparison with directly measured forces (Helmuth \& Denny 2003). On a geographical scale, variation in wave height offshore may contribute significantly to differences in wave exposure of sites of similar wave fetch in different regions. In the UK, for example, the Meteorological Office UK Wave Model (Anonymous 1998) shows that western coasts of Scotland receive much larger waves than eastern coasts: the 90th percentile offshore wave height for open western coasts of the Scottish Western Isles is around $4 \mathrm{~m}$, while for the Scottish east coast the 90th percentile is only $2.5 \mathrm{~m}$.

While incorporating the most important determinant of coastal wave forces (wave fetch) topographical indices calculated here provide only a surrogate for the aspects of wave climate important in determining rocky shore community structure. Significant progress may only be possible through application of physical models of inshore waves, such as the SWAN wave model (Simulating WAves Nearshore; Booij et al. 1999), combined with direct observations of offshore wave heights from wave buoys or satellite altimeter measurements. Such developments are beyond the scope of most field ecologists and, thus, until more complex physical models are widely applied, wave fetch indices are likely to remain useful for some time.

Greater spatial resolution in the grid used to calculate the wave fetch index gave increasing predictive power up to a maximum value at a grid cell size of $200 \mathrm{~m}$. Increasing the resolution further to a $100 \mathrm{~m}$ cell size decreased predictive power. The map scale of the original coastline (1:250 000, NOAA; see: www.ngdc. noaa.gov/mgg/shorelines/gshhs.html) suggests a minimum justifiable raster resolution of $125 \mathrm{~m}$, potentially contributing to the drop in performance at the $100 \mathrm{~m}$ scale. In addition, the greater extent of the sampling area $(100$ to $200 \mathrm{~m})$ than the grid cells may lead to an increased chance of spatial mismatch between the wave fetch index and the location of the sample. Finerscale models may well be able to resolve variation in wave action that might result in within-site heterogeneity in biological communities (Denny et al. 2004).

The strong predictive capability of the wave fetch index and the ability to make ubiquitous calculations over whole regions makes it an ideal tool for classifying and mapping coastal habitats and biotopes. While this will be useful for managers of coastal areas, it may also prove useful for making biomass-weighted estimates of the functioning of coastal ecosystems, by allowing the prediction of the extent and quantity of dominant species of primary producers (Lindegarth \& Gamfeldt 2005) or filter feeders (Westerbom \& Jattu 2006).

Perhaps the most useful aspect of the wave fetch index is that it allows the separation of wave exposure related variation from variation due to other factors. While some of this remaining variation may be due to the incomplete description of the wave regime at the sites (as above), the remaining variation will be due to (1) responses to other physical factors varying among sites, such as local geology including rock types and bed forms; (2) the outcome of interactions among species, driven by variation in recruitment (Sutherland \& Ortega 1986, Connolly \& Roughgarden 1999, Menge et al. 2003, Forde \& Doak 2004); and (3) responses to food supply from the nearshore pelagic system (Sanford \& Menge 2001, Menge et al. 2003, Leslie et al. 2005). The balance between fucoid macroalgae and filter feeders such as barnacles and mussels, for example, is thought to be controlled on rocky shores in the northeast Atlantic by the activity of intertidal grazers, particularly patellid limpets (Jenkins et al. 2005, Coleman et al. 2006). The population density and size of Patella vulgata, the major species of limpet in the region, are correlated with wave exposure, with limpets usually smaller and more numerous at wave-exposed sites (Jenkins \& Hartnoll 2001). However, much variation in abundance and biomass of limpets, and consequent grazing pressure, may remain, and could potentially account for some of the variation in the quantity of macroalgae, as indicated by the PCA1 score in the analysis here, among shores of similar wave exposure. A macroecological approach using studies of many sites simultaneously, where physical and biological factors can be statistically separated, offers much potential for new insight into processes determining community structure in these and similar systems.

Acknowledgements. This work was supported by the NERCfunded 'Northern Seas Programme' at the Scottish Association for Marine Science and by the MarClim project (www.mba.ac.uk/marclim), funded by the Countryside Council for Wales, The Crown Estates, Department for Environment, Food and Rural Affairs, English Nature, Environment Agency, Joint Nature Conservation Committee, Scottish Executive, Scottish Natural Heritage, States of Jersey and Worldwide Fund for Nature. A. Davies and S. Gontarek helped with GIS issues. We also thank those land owners who kindly allowed us access to the shore at various sites around Scotland, and the UK Met Office and the British Atmospheric Data Centre for providing wind data. The manuscript was much improved by the comments of 4 anonymous referees. 


\section{LITERATURE CITED}

Anonymous (1998) Assessment of significant wave height in UK coastal waters. Report prepared for the Maritime and Coastguard Agency. The UK Met Office Marine Consultancy Service, London

Araújo MB, Pearson RG, Thuiller W, Erhard M (2005) Validation of species-climate impact models under climate change. Global Change Biol 11:1504-1513

Ballantine WJ (1961) A biologically-defined exposure scale for the comparative description of rocky shores. Field Stud 1:1-19

Beck MW (2000) Separating the elements of habitat structure: independent effects of habitat complexity and structural components on rocky intertidal gastropods. J Exp Mar Biol Ecol 249:29-49

Bekkby T, Erikstad L, Bakkestuen V, Bjørge A (2002) A landscape ecological approach to coastal zone applications. Sarsia 87:396-408

Booij N, Ris RC, Holthuijsen LH (1999) A third-generation wave model for coastal regions, Part I. Model description and validation. J Geophys Res Oceans 104:7649-7666

Burrows MT, Hawkins SJ, Southward AJ (1992) A comparison of reproduction in co-occurring chthamalid barnacles, Chthamalus stellatus (Poli) and Chthamalus montagui Southward. J Exp Mar Biol Ecol 160:229-249

Coleman RA, Underwood AJ, Benedetti-Cecchi L, Åberg P and others (2006) A continental scale evaluation of the role of limpet grazing on rocky shores. Oecologia 147: 556-564

Connolly SR, Roughgarden J (1999) Theory of marine communities: competition, predation and recruitmentdependent interaction strength. Ecol Monogr 69:277-296

Crisp DJ, Southward AJ (1958) The distribution of intertidal organisms along the coasts of the English Channel. J Mar Biol Assoc UK 37:157-208

Crothers JH (1983) Variation in dogwhelk shells in relation to wave action and crab predation. Biol J Linn Soc 20:85-102

Crothers JH, Cowell EB (1979) On variation in Nucella lapillus (L.) shell shape in populations from Fensfjorden, Norway: an applied example. J Molluscan Stud 45:108-114

Davies AJ, Johnson MP (2006) Coastline configuration disrupts the effects of large-scale climatic forcing, leading to divergent temporal trends in wave exposure. Estuar Coast Shelf Sci 69:643-648

Denny MW (1982) Forces on intertidal organisms due to breaking ocean waves: design and application of a telemetry system. Limnol Oceanogr 27:178-183

Denny MW, Helmuth B, Leonard GH, Harley CDG, Hunt LJH, Nelson EK (2004) Quantifying scale in ecology: lessons from a wave swept shore. Ecol Monogr 74:513-532

Ekebom J, Laihonen P, Suominen T (2003) A GIS-based stepwise procedure for assessing physical exposure in fragmented archipelagos. Estuar Coast Shelf Sci 57:887-898

Forde SE, Doak DF (2004) Multitrophic interactions mediate recruitment variability in a rocky intertidal community. Mar Ecol Prog Ser 275:33-45

Gaston KJ, Blackburn TM (1999) A critique for macroecology. Oikos 84:353-368

Harborne AR, Mumby PJ, Zychaluk K, Hedley JD, Blackwell PG (2006) Modeling the beta diversity of coral reefs. Ecology 87:2871-2881

Helmuth B, Denny MW (2003) Predicting wave exposure in the rocky intertidal zone: Do bigger waves always lead to larger forces? Limnol Oceanogr 48:1338-1345

Hiscock K (1981) The rocky shore ecology of Sullom Voe. Proc R Soc Edinb Sect B (Biol) 80:219-240

Editorial responsibility: Otto Kinne (Editor-in-Chief), Oldendorf/Luhe, Germany
Jenkins SR, Hartnoll RG (2001) Food supply, grazing activity and growth rate in the limpet Patella vulgata L.: a comparison between exposed and sheltered shores. J Exp Mar Biol Ecol 258:123-139

Jenkins SR, Coleman RA, Della Santina P, Hawkins SJ, Burrows MT, Hartnoll RG (2005) Regional scale differences in the determinism of grazing effects in the rocky intertidal. Mar Ecol Prog Ser 287:77-86

Johnson MP, Frost NJ, Mosley MWJ, Roberts MF, Hawkins SJ (2003) The area-independent effects of habitat complexity on biodiversity vary between regions. Ecol Lett 6:126-132

Jones WE, Demetropoulos A (1968) Exposure to wave action; measurements of an important ecological parameter on rocky shores of Anglesey. J Exp Mar Biol Ecol 2:46-63

Leslie HM, Breck EN, Chan F, Lubchenco J, Menge BA (2005) Barnacle reproductive hotspots linked to nearshore ocean conditions. Proc Natl Acad Sci USA 102:10534-10539

Lewis JR (1964) The ecology of rocky shores. English Universities Press, London

Lindegarth M, Gamfeldt L (2005) Comparing categorical and continuous ecological analyses: effects of 'wave exposure' on rocky shores. Ecology 86:1346-1357

Menge BA, Lubchenco J, Bracken MES, Chan F and others (2003) Coastal oceanography sets the pace of rocky intertidal community dynamics. Proc Natl Acad Sci USA 100: 12229-12234

Paine RT (1966) Food web complexity and species diversity. Am Nat 100:65-75

Palumbi SR (1984) Measuring intertidal wave forces. J Exp Mar Biol Ecol 81:171-179

Pearson RG, Dawson TP (2003) Predicting the impacts of climate change on the distribution of species: Are bioclimate envelope models useful? Global Ecol Biogeogr 12:361-371

Pearson RG, Dawson TP, Berry PM, Harrison PA (2002) SPECIES: a spatial evaluation of climate impact on the envelope of species. Ecol Modell 154:289-300

Puotinen ML (2005) An automated GIS method for modelling relative wave exposure within complex reef-island systems: a case study of the Great Barrier Reef. In: Zerger A, Argent RM (eds) Proceedings MODSIM05 International Congress on Modelling and Simulation. Modelling and Simulation Society of Australia and New Zealand, December 2005, p 1437-1443. Available at: www.mssanz.org.au/ modsim05/papers/puotinen.pdf

Richardson AJ, Schoeman DS (2004) Climate impact on plankton ecosystems in the northeast Atlantic. Science 305:1609-1612

Ruuskanen A, Bäck S, Reitalu T (1999) A comparison of two cartographic exposure methods using Fucus vesiculosus as an indicator. Mar Biol 134:139-145

Sanford E, Menge BA (2001) Spatial and temporal variation in barnacle growth in a coastal upwelling system. Mar Ecol Prog Ser 209:143-157

Stephenson TA, Stephenson A (1972) Life between tidemarks on rocky shores.WH Freeman, San Francisco, CA

Sutherland JP, Ortega S (1986) Competition conditional on recruitment and temporary escape from predators on a tropical rocky shore. J Exp Mar Biol Ecol 95:155-166

Thomas MLH (1986) A physically derived exposure index for marine shorelines. Ophelia 25:1-13

Thompson RC, Wilson BJ, Tobin ML, Hill AS, Hawkins SJ (1996) Biologically generated habitat provision and diversity of rocky shore organisms at a hierarchy of spatial scales. J Exp Mar Biol Ecol 202:73-84

Westerbom M, Jattu S (2006) Effects of wave exposure on the sublittoral distribution of blue mussels Mytilus edulis in a heterogeneous archipelago. Mar Ecol Prog Ser 306:191-200 